\title{
Observation of Aqua-Bio fertilizer nutrients influence of Trigonella foenum- graecum L. growth in mediated Aquaponics system for food security.
}

\author{
Manjula, $D^{1}$, and Raja, $S^{2 *}$ \\ ${ }^{1}$ Department of Zoology, Kongunadu Arts and Science College, Coimbatore-641 029, Tamil Nadu, India. \\ ${ }^{2}$ Department of Zoology, Kongunadu Arts and Science College, Coimbatore-641 029, Tamil Nadu, India. \\ *Corresponding Author: rajaselvaraju12@gmail.com, Mob. No. 919442694822
}

Available online at: www.isroset.org

Received: 21/Mar/2019, Accepted: 10/Apr/2019, Online: 30/Apr/2019

\begin{abstract}
The conception of Aquaponics is a synergistic combination of aquaculture and hydroponics that nurture plants with aquaculture water. It is the internationally improved agricultural practices, are needed to assuage rural poverty and enhance food security. Aquaponics is a soil-less combined approach to proficient and sustainable intensification of agriculture that meets the needs of water scarcity inventiveness and generated modern farming practices in agriculture. The nutrient-rich fish water from the fish tanks is used to fertigate hydroponic production beds. To improve the production efficiency can be used bio fertilizers (Aquaponic water and Gracilaria corticata extract) as a liquid it contains organic macro, micronutrient and growth hormones. Tilapia fish produced the nutrient that is utilized by the plant Trigonella foenum- graecum $L$. The Physico-chemical parameter of both bio fertilizers should be assessed by using the standard procedures. The fish effluent water is compared with the Gracilaria corticata red seaweed extract by foliar spray and combining with both liquid bio fertilizers (Aquaponic water and seaweed extracts). Morphological growths of the plants were assessed. The combination of Aquaponic water and Gracilaria corticata seaweed extract was given the good result, but the estimation $(15.26 \pm 0.29,24.06 \pm 0.27,30 \pm 0.64,35.94$ $\pm 0.28 \mathrm{~cm}$ plant height at $7,14,21$ and 28 DAS) $(2.6 \pm 0.1$ branches at 30, DAS) $(533.67 \pm 11$ and $51 \pm 1 \mathrm{mg}$ shoot and root fresh weight per plant) leaf area $(46.62 \pm 0.89 \mathrm{~cm} 2)$ at 28 DAS was related to the Aquaponic water in the plant Trigonella foenum- graecum $L$. Thus, the present result revealed that the integrated aquaponic system is the new agricultural farming systems with liquid bio fertilizers are eco- friendly practice for food security.
\end{abstract}

Keywords: Aquaponics, Tilapia fish, Trigonella foenum- graecum L., Gracilaria corticata seaweed and liquid biofertilizer, eco-friendly

\section{INTRODUCTION}

Aquaponics is an integrated method that combines recirculating aquaculture and hydroponics [34], in which the water from the fish tanks that is enriched in nutrients is used for plant growth. Lehman et al., (1993) deliberated a sustainable agriculture as a process that does not exhaust any non-renewable resources that are fundamental to agriculture in order to endure the farming practices. Francis et al., (2003) append that sustainable agricultural production can be achieved by resembling natural ecosystems and "designing systems that close nutrient cycles", which is the main characteristics of Aquaponics. The absolute product of bacterial conversion is a nitrate, which the main nitrogen source for plant growth in an Aquaponic system [12, 15, 35]. The lower nutrient concentrations are acceptable for an Aquaponics system because the nutrients are produced daily with the fish metabolic activities as well as mineralization of organic matter $[36,16]$. Conventional hydroponics necessitate mineral fertilizers in order to supply the plants with necessary nutrients, but the Aquaponics systems use the obtainable fish water that is rich in fish waste as nutrients for plant growth. The synergistic interaction of aquaculture and hydroponics are converted into strengths. This combination significantly minimizes the need for input of nutrients and output of waste, unlike when running as separate systems. Minerals transfer from aquaculture to hydroponics support efficient nutrient recycling and relatively safe food (fish and vegetables) [49]. Media-filled grows bed is the most popular intention of small-scale Aquaponics. This method is strongly recommended for most developing areas. This type has well-organized with space, low cost and are suitable for beginners because of their simplicity [30]. It was filled with coco peat because it has a pH neutral, low-cost, lightweight, highwater retention; support the plant in the medium level, easy to work but short lifespan [18]. The Trigonella foenum-graecum $\mathrm{L}$. (Fenugreek) plants are grown in the media bed. It is the medicinal plant from the Fabaceae family originated in central Asia [1]. Its green leaves containing $\beta$-carotene $(19 \mathrm{mg} / 100 \mathrm{~g})$, ascorbate $(220 \mathrm{mg} / 100 \mathrm{~g})$ [48], fiber, iron, calcium and zinc even 
more than the regular food items [27]. The leaves and seedling of fenugreek are eaten as greens. The leaves have a bitter taste and a unique odour [44]. Moreover, the Tilapia (Oreochromis niloticus) fish has many favorable characteristics like poor water quality, wide salinity ranges, water temperature ranges, low dissolved oxygen levels, and elevated ammonia concentrations adopt in Aquaponic production [31]. Therefore, we have conducted experiments on Tilapia fish in this system.

\section{Gracilaria corticata is used as a liquid fertilizer}

Gracilaria corticata Seaweed (marine macroalgae) has been used as fertilizer help to promote plant growth. The extract of this seaweed signs successful seed germination, saplings development, increase plant tolerance to environmental pressures [52,53] and improve plant growth and yield [17,55,20,21,6]. Foliar application of seaweed liquid gives many beneficial effects on the plant growth as they contain growth-promoting hormones (IAA, IBA and Cytokinins) [5,10,19]. Seaweed liquid is available in the market as liquid bio-fertilizer. Therefore, in this present study aimed to prove the Aquaponic water and seaweed liquid is the Aqua-biofertilizer with the growth performance of Trigonella foenum-graecum L. plants in the Oreochromis niloticus (Tilapia) mediated Aquaponic system.
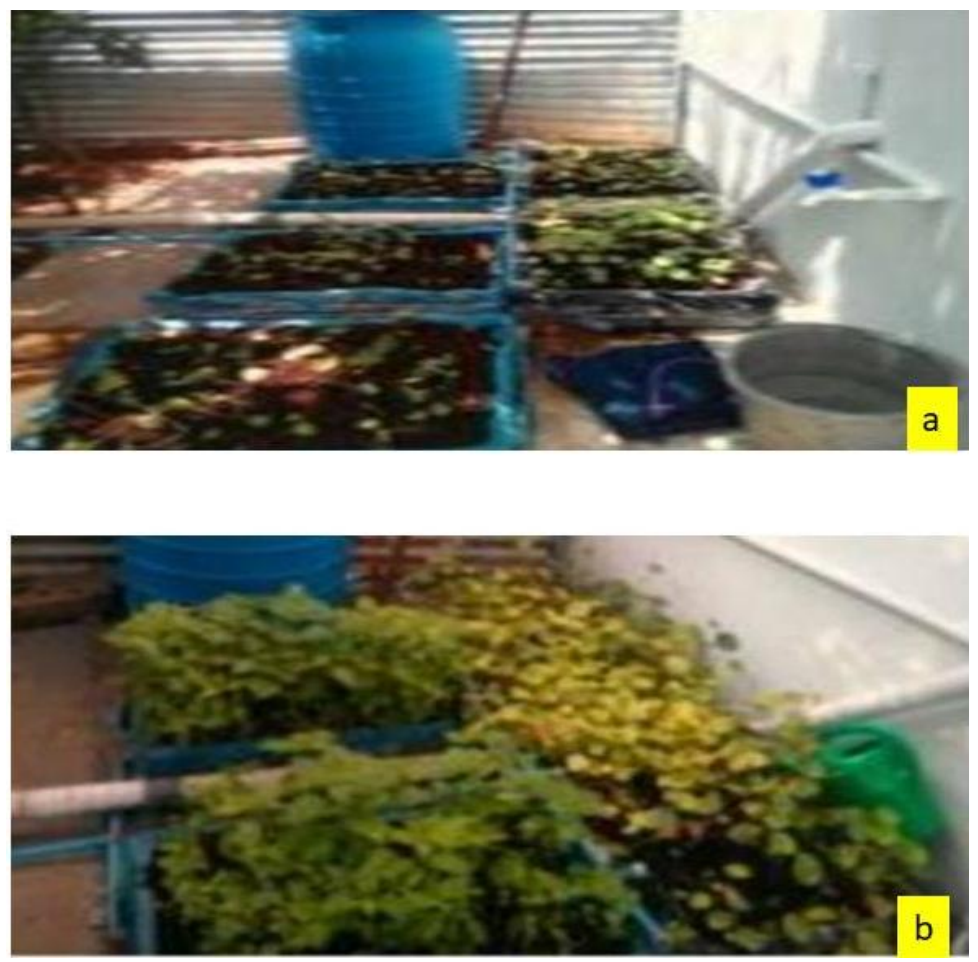

Aquaponic System. a denotes Media Filled Aquaponic system; b represents plants grown in the Aquaponic System.

\section{MATERIALS AND METHODS}

The Aquaponic system was designed according to Bernstein (2014) model. The Aquaponic system was comprised of two fish tanks about 142 litres. The fish tanks were covered with aluminum net, it prevents fish from jumping out and prevent leaves, debris from entering and prevent predators such as cats and birds from attacking the fish. The tap water was located near the rearing tanks, supplied water for a short distance to the fish rearing tank. The conformity of nitrification and nutrient availability in the Aquaponics system was acquired $\mathrm{pH}=7$. The fish tanks were aerated with 10-watt motor to avoid insufficient oxygen level. The water from the fish tanks were flowed by the gravity and then it was entering the hydroponic grow bed. The pipes were plumped to join media- filled grow bed with the fish tank having inlet and outlet of water. An overflow pipe was set at $10 \mathrm{~cm}$ for maintaining a constant water level in the plant bed. The hydroponics media- filled grow bed was filled with Aquaponic water; it was drained and entered into the sump tank. The capacity of the sump tanks were 20 liters. It was the lowest part of the system. The submersible pump was fitted inside the sump tank that was returned the treated culture water to the rearing tank. The procedure was followed in both the tanks. About 20 nos of $2.5 \mathrm{~cm}$ length and 4-6 gm Tilapia fingerlings 
were bought from the Ukkadam Periyakulam, Coimbatore, Tamil Nadu. Further, they were fed with floating feed three times a day with $12.0 \mathrm{gms}$, fish food containing $32 \%$ protein.

\subsection{Media filled grow bed}

Trigonella foenum- graecum L. plant was grown in the coconut peat as a medium. The four media filled grow beds were chosen for plant cultivation [3], the wooden frame with watertight polyethylene sheeting on the base and inside the walls. The beds were filled with coco peat. The size of the media beds was $50 \mathrm{~cm}$ x $30 \mathrm{~cm}$ x $40 \mathrm{~cm}$ in the rectangular shape. The water holding capacity or volume of the four beds was 45 litres. Beds are designed to flood-and-drain. The first tank was connected with the $\mathrm{T}_{2}$ grow bed and another tank was connected with the $\mathrm{T}_{4}$ grow bed.

\subsection{Collection of the seed}

The Trigonella foenum- graecum L plant seeds were bought in the Tamil Nadu Agricultural University (TNAU), Coimbatore. The seeds with uniform size, color and weight were chosen for the experimental purpose. A hundred seeds were soaked in the water overnight for germination. The four grow beds were directly sown with seeds. In each media-filled grow bed 25 seeds were sown because it was helped to measure the seed germination days. The procedure was followed in each grow bed.

\subsection{Collection of seaweed}

The seaweed was collected in Ramanathapuram district, Tamil Nadu in the latitude of $9^{\circ} 17^{\prime} \mathrm{N}$ and longitude of $80^{\circ} 10^{\prime}$. The extract was prepared from the red seaweed Gracilaria corticata. About $1 \mathrm{~kg}$ of fresh and healthy seaweed was collected. The sample was washed thoroughly in seawater followed by tap water to remove the extraneous materials and sand particles.

\subsection{Preparation of seaweed liquid fertilizer}

The freshly collected seaweed was shade dried for ten days that dried material was finely powdered. From the dried powder, 50 grams of powder were extracted with $500 \mathrm{ml}$ of boiling water for $60 \mathrm{~min}$ and then filtered. The resulting extract was cooled and taken as a $100 \%$ concentration of the SLF [37]. The seaweed liquid fertilizer was refrigerated between $0{ }^{\circ} \mathrm{C}$ and $4{ }^{\circ} \mathrm{C}$.

\subsection{Experimental design and treatments}

The effect of Aquaponic fish effluent water and seaweed extracts on the growth of fenugreek was evaluated using various treatments applied as coco peat used media filled grow beds. The treatment dose was $20 \%$ seaweed liquid fertilizer. $[54,33]$. Low concentration is effective for greens. The seaweed liquid fertilizer was given weekly once.

$\mathrm{T}_{1}$ grow bed was a control, $\mathrm{T}_{2}$ was Aquaponic water, $\mathrm{T}_{3}$ was seaweed liquid fertilizer $(20 \%)$ and $\mathrm{T}_{4}$ was Aquaponic water and $20 \%$ seaweed liquid fertilizer.

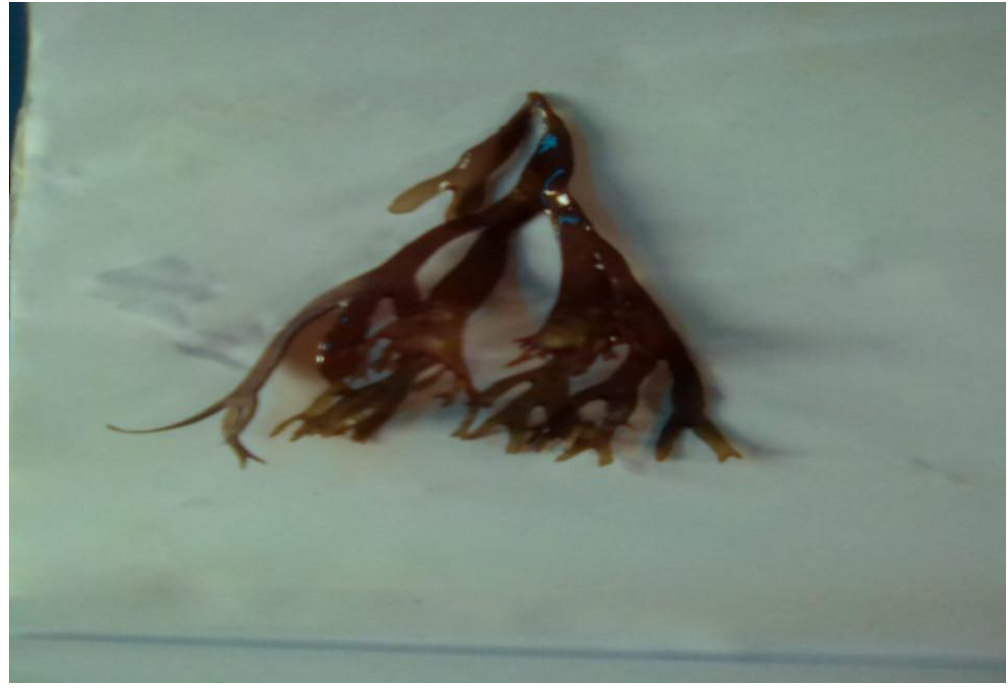

Figure 1. Seaweed, Gracilaria corticata 
Table 1 Experimental design with different treatments.

\begin{tabular}{|l|l|l|}
\hline S.No & Experiment & Component of Experiment \\
\hline 1 & T1 & Cocopeat+Tapwater \\
\hline 2 & T2 & Cocopeat+Aquaponic fish effluent water \\
\hline 3 & T3 & Cocopeat+Gracilaria corticata seaweed liquid extract \\
\hline 4 & T4 & Cocopeat+ Aquaponic fish effluent water+Gracilaria seaweed extract. \\
\hline
\end{tabular}

\subsection{Physico-chemical properties of Aquaponic water and Gracilaria corticata seaweed}

The physico-chemical parameter such as pH (Hanna, HI98107), Calcium, and Magnesium, Sodium, and Potassium (Varian spectra-220AA atomic absorption spectrophotometer) of Aquaponic water and seaweed extract were recorded.

The growth parameter of Trigonella foenum- graecum $L$ plant was observed at 7days interval that included average height (by meter rule), seed germination, and the leaf area was calculated (LA=0.5*L*W, Where: LA=Leaf area) [32]. The average number of plant branches was counted and measured in biomass. The results were performed by using Microsoft Excel, 2010.

\section{RESULTS AND DISCUSSION}

\subsection{Macro and micronutrients present in the aquaponic water:}

Macro and Micronutrients of the Aquaponic water values were shown in the Tables 2 and 3. The results showed that Ammonium concentration level in the Aquaponic water and Nitrate levels were $0.35 \pm .02 \mathrm{mg} / \mathrm{l}$ and $37 \pm 1.2 \mathrm{mg} / \mathrm{l} \mathrm{respectively}$, nitrate level was higher in Aquaponic water. Phosphate is an important ingredient nutrient. This value of phosphate found in Aquaponic water was marked as $11 \pm 1.15 \mathrm{mg} / \mathrm{l}$. The potassium level was recorded as $26 \pm 1.15 \mathrm{mg} / \mathrm{l}$. Calcium and Magnesium levels were $30 \pm .6 \mathrm{mg} / \mathrm{l}$ and $16.2 \pm .8 \mathrm{mg} / \mathrm{l}$. The micronutrients of the Iron level was recorded as $0.2 \pm .06 \mathrm{mg} / \mathrm{l}$. Zinc and manganese content were at the scale $0.4 \pm .0601 \mathrm{mg} / 1,0.08 \pm .01 \mathrm{mg} / 1$ (Table 2).

Aquaponic water as noted by Licamele (2009) observed higher growth (50 mg/l N-Nitrate) in Lactuca sativa in an aquaponic integrated system. Similarly, the present result indicated that higher plant growth (Trigonella foenum- graecum L) as observed in Aquaponic water was $37 \mathrm{mg} / \mathrm{l}$. Endut et al., (2011) observed that the phosphorus (P) concentration of aquaponic water was within the above limit. The present result also indicated a similar aquaponics system. The minimal concentration of aquaponic water was acceptable to the plants in the form of continuous aquaponic fish effluent. This concentration has been found to be sufficient for the plant growth because the available nutrient was often enriched by the aquaponic water. It helped the root formation along with the growth. Villarroel et al., (2011) reported that the growth of strawberry was higher with potassium concentration at $9-15 \mathrm{mg} / \mathrm{l}$, while using aquaponic water (Oreochromis niloticus). The present result also indicated that the concentration at the level $26 \pm 1.15 \mathrm{mg} / \mathrm{l}$, has been solely responsible for the higher plant growth with enhanced photosynthetic efficiency. Tomasi et al., (2009); De Vleesschauwer et al., (2008); Schalk et al., (2011) reported that the concentration of Iron, Zinc and manganese could be delivered to the plants, especially the shoot system, leaves has been prevented pathogen attack for a long time and also reported that the ability of these molecules to induce systemic resistance in the tomato cultivation.

Table 2 Macronutrients in the Aquaponic water and Gracilaria corticata liquid seaweed

\begin{tabular}{|l|l|l|l|}
\hline S.No & Macronutrients & Aquaponic water $(\mathrm{mg} / \mathrm{L})$ & $\begin{array}{l}\text { Gracilaria corticata } \\
\text { seaweed liquid (mg/L) }\end{array}$ \\
\hline 1 & Ammonium & $0.4 \pm 0.02$ & - \\
\hline 2 & Nitrate & $37 \pm 1.2$ & $56 \pm 0.4$ \\
\hline 3 & Phosphate & $11 \pm 1.15$ & $15 \pm 0.3$ \\
\hline 4 & Magnesium & $16 \pm 0.8$ & $49 \pm 0.7$ \\
\hline 5 & Calcium & $30 \pm 0.6$ & $72 \pm 0.6$ \\
\hline 6 & Potassium & $26 \pm 1.15$ & $10 \pm 1.8$ \\
\hline
\end{tabular}




\subsection{Macro and micronutrients present in the Gracilaria corticata seaweed}

Nitrate level in the Gracilaria corticata seaweed was $56 \pm 0.4 \mathrm{mg} / \mathrm{l}$. Calcium, Magnesium, Potassium and Phosphorus level were $72 \pm 0.6,49 \pm 0.7,10.11 \pm 1.8$ and $15 \pm 0.3 \mathrm{mg} / \mathrm{l}$ (Table 2). Iron, Manganese, and Zinc present in the seaweed were $0.44 \pm 0.9$, $0.32 \pm 0.3,0.75 \pm 0.3 \mathrm{mg} / \mathrm{l}$ (Table 3). Macro and micronutrients and growth hormones found in the seaweed were supporting the plant growth [13,54,33]. It was reported that the presence of plant growth regulators and nutrients in the low concentration of SLF enhanced the growth of root and shoot [28]. Growth hormones Auxin, Cytokinin and Gibberellin levels in the Gracilaria corticata were 3.1, 9.3 and $5.2 \mathrm{mg} / \mathrm{l}$ respectively (Table 4). They play a pivotal role in the growth of plants. Auxin increases the production and let water enter into the cells, activating H-ATPase pumps. This procedures lead to the growth of cells and simultaneously helps the growth of plants [46]. The findings reported the presence of auxin in the extracts of Ascophyllum nodosum [39] and Ulva sp., in the extracts of cytokinins [41]. The present study showed that extracts from the Gracilaria corticata has been instrumental in promoting the growth characteristics of fenugreek plants.

\section{Table 3 Micronutrients in the Aquaponic water and liquid of Gracilaria corticata}

\begin{tabular}{|c|c|c|c|}
\hline $\begin{array}{l}\text { S. } \\
\text { No }\end{array}$ & Micro nutrients & $\begin{array}{l}\text { Aquaponic water } \\
(\mathrm{mg} / \mathrm{L})\end{array}$ & $\begin{array}{l}\text { Gracilaria corticata seaweed liquid } \\
(\mathrm{mg} / \mathrm{L})\end{array}$ \\
\hline 1 & Iron & $0.2 \pm .1$ & $0.44 \pm 0.9$ \\
\hline 2 & $\mathrm{Mn}$ & $0.4 \pm .06$ & $0.32 \pm 0.3$ \\
\hline 3 & $\mathrm{Zn}$ & $0.08 \pm .01$ & $0.75 \pm 0.5$ \\
\hline
\end{tabular}

Mean \pm SE

Table 4 Growth Hormone (GH) in the liquid seaweed of Gracilaria corticata

\subsection{Morphological Analysis}

\begin{tabular}{|l|l|l|}
\hline S.No & Growth Hormones & Gracilaria corticata $(\mathrm{mg} / \mathrm{l})$ \\
\hline 1 & Auxin & 3.1 \\
\hline 2 & Cytokinin & 9.3 \\
\hline 3 & Gibberellin & 5.2 \\
\hline
\end{tabular}

\subsection{Seed germination of Trigonella foenum- graecum $l$. Plant}

The seed germination was observed in the Trigonella foenum- graecum L. (Fig.1) seed, which was used in the different substratum. A hundred seeds were selected for germination. The seeds were soaked in the distilled water overnight, then 25 seeds were being sown in each grows bed. In the Aquaponic water mixed with foliar sprays of Gracilaria seaweed, seeds germinated within 2 days. The similar result was observed and followed by the Gracilaria corticata seaweed used in the media bed, the seeds germinated in 3 days and in control media bed it took 4 days. This result indicated that the aquaponic water used with seaweed extract seeds has a higher growth rate while compared to the Gracilaria seaweed and the control.

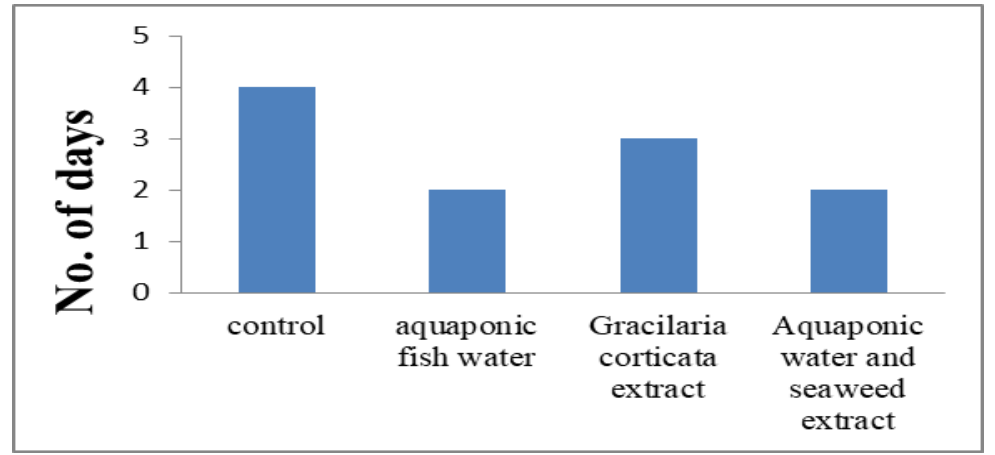

Figure 2. Seed germination of Trigonella foenum-graecum 


\subsection{Plant height (cm)}

The plant height was recorded at 7,14,21, and 28 days after sown (DAS). The average fenugreek plant height was depicted in the Table5, as clearly indicated in different treatments. Treatment T4 (Aquaponic fish water+ seaweed liquid fertilizer) was found significantly superior plant height $(15.26 \pm 0.29,24.06 \pm 0.27,30 \pm 0.64,35.94 \pm 0.28 \mathrm{~cm}$ plant height of 7, 14, 21and 28 DAS) followed by T2 (Aquaponic water) $(14.14 \pm 0.99,21.42 \pm 1.08,28.14 \pm 1.39$ and $34.28 \pm 0.54 \mathrm{~cm}$ plant height) and T3 (seaweed liquid fertilizer) $(9.46 \pm 1.02,17.68 \pm 1.17,23.9 \pm 1.42$ and $30.22 \pm 0.80 \mathrm{~cm}$ plant height). The lowest growth was observed under the treatment T1 (control) (7.02 $\pm 3.8912 .20 \pm .2917 .60 \pm .63$ and $25.58 \pm 0.64 \mathrm{~cm}$ plant height) at 7, 14, 21 and 28 DAS respectively. This may be due to the application of major and minor nutrient level through liquid bio-fertilizer that helped to increase the photosynthetic activity, Chlorophyll formation, Nitrogen metabolism and Auxin contents in the plants ultimately improving the plant height. These findings are also comparable with the findings of Subramanian and Vijayakumar (2001) Malhotra et al. (2006) in fenugreek.

Table 5 plant height of fenugreek at 7, 14, 21, 28 days

\begin{tabular}{|c|c|c|c|c|}
\hline \multirow[b]{2}{*}{ Treatment } & \multicolumn{4}{|c|}{ No of days $(\mathrm{cm}) \mathrm{N}=5$} \\
\hline & 7 & 14 & 21 & 28 \\
\hline Control & $7.02 \pm 3.89$ & $12.20 \pm .29$ & $17.60 \pm 0.63$ & $25.58 \pm 0.64$ \\
\hline Aquaponic water & $14.14 \pm 0.99$ & $21.42 \pm 1.08$ & $28.14 \pm 1.39$ & $34.28 \pm 0.54$ \\
\hline Seaweed liquid & $9.46 \pm 1.02$ & $17.68 \pm 1.17$ & $23.9 \pm 1.42$ & $30.22 \pm 0.80$ \\
\hline Aquaponic +seaweed liquid & $15.26 \pm 0.29$ & $24.06 \pm 0.27$ & $30 \pm 0.64$ & $35.94 \pm 0.28$ \\
\hline
\end{tabular}

Mean \pm SD

\subsection{Number of branches per}

The number of branches per plant was recorded at 28DAS present in Table 6. Treatment T4 (Aquaponic fish effluent water+ seaweed liquid fertilizer) was found higher $(2.6 \pm 0.1$ branches in 28 , DAS) followed by T2 (Aquaponic fish effluent water) ( $2.2 \pm 0.18$ branches), T3 (seaweed liquid fertilizer, $2.06 \pm 0.08$ branches). While the lowest branches noted in the treatment T1 (control) (1.28 \pm 0.23 branches) at 30 DAS. Similar results have been reported by Datta et al., 2005), and Nehara et al., (2002). These findings relate to the findings of Malhotra et al. (2006) reported that the Azospirillum sp. The number of branches was increased by greater nitrogen levels. The probable reason for the increased number of branches due to the improved rates of photosynthesis, supplied essential nutrients for maximum branch growth or change in auxin apical dominance.

\subsection{Shoot and Root weight per plant (mg.)}

The shoot and root weight of the fenugreek plant increased within the different treatments were given in Table 6 . The maximum $533.67 \pm 11$ and $51 \pm 1 \mathrm{mg}$ shoot and root fresh weight per plant was recorded in treatment T4 (Aquaponic fish effluent water+ seaweed liquid fertilizer), followed by T2 (Aquaponic fish effluent water) $(481 \pm 5.5,51 \pm 1 \mathrm{mg}$ ), T3 (seaweed liquid fertilizer) $(450.67 \pm 7.09,46 \pm 1 \mathrm{mg})$ and While the lowest shoot and root weight was found inT1 (control) $(410.67 \pm 11$, $43.3 \pm 1.5 \mathrm{mg}$ ). This may be due to the application of major and minor nutrients, through both liquid bio-fertilizer. Ultimately, improve the plant growth fresh weight and dry weight of the plant. These results were concurred with the findings of Sharma (2006), Subramanian and Vijayakumar (2001), Mehta et al. (2012) in fenugreek.

Table 6. Number of branches per plant, shoot and root fresh weight of fenugreek at 28 days

\begin{tabular}{|c|c|c|c|c|}
\hline \multirow[b]{2}{*}{ Attributes } & \multicolumn{4}{|c|}{ Treatment after the 28 days } \\
\hline & Control & Aquaponic & Seaweed & Aquaponic+seaweed \\
\hline Shoot fresh weight (mg/plant) & $410.67 \pm 11$ & $481 \pm 5.5$ & $450.67 \pm 7.09$ & $533.67 \pm 11$ \\
\hline Branches & $1.28 \pm 0.23$ & $2.2 \pm 0.18$ & $2.06 \pm 0.08$ & $2.6 \pm 0.1$ \\
\hline
\end{tabular}

Mean \pm SD

\subsection{Leaf area}


The data (Table 7) revealed that the difference among treatments with the leaf area at different stages of plant growth. The mean leaf area increased from $1.14 \pm 0.13 \mathrm{~cm}^{2}$ at 7 DAS to $46.62 \pm 0.89 \mathrm{~cm}^{2}$ at 28 DAS. The aquaponic water showed a maximum leaf area $\left(46.62 \pm 0.89 \mathrm{~cm}^{2}\right)$ at $28 \mathrm{DAS}$, whereas, the control showed the minimum leaf area $\left(24.04 \pm 0.61 \mathrm{~cm}{ }^{2}\right)$ at 28 DAS. The number of leaves is dependent largely upon the number of nodes and also on the number of branches both primaries and secondaries arising on the main shoot of the plant. The findings were harmony with the results of Nehara et al., (2002).

Table 5 plant height of fenugreek at 7, 14, 21, 28 days

\begin{tabular}{|l|l|l|l|l|}
\hline \multirow{2}{*}{ Treatment } & \multicolumn{5}{|c|}{ No of days (Cm $/$ plant $)$} \\
\cline { 2 - 5 } & 7 & 14 & 21 & 28 \\
\hline Control & $1.14 \pm 0.13$ & $2.12 \pm 0.13$ & $11.32 \pm 0.19$ & $24.04 \pm 0.61$ \\
\hline Aquaponic & $2.24 \pm 0.25$ & $5.36 \pm 0.27$ & $24.64 \pm 0.47$ & $43.34 \pm 0.24$ \\
\hline Seaweed & $2.2 \pm 0.25$ & $4.74 \pm 0.11$ & $22.62 \pm 0.40$ & $38.12 \pm 0.13$ \\
\hline Aqua+seaweed & $2.66 \pm 0.27$ & $5.44 \pm 0.23$ & $27.2 \pm 0.83$ & $46.62 \pm 0.89$ \\
\hline
\end{tabular}

Mean \pm SD

\section{CONCLUSION}

This study concludes that Aquaponic water and seaweed liquid fertilizers are Aqua bio-fertilizers and eco-friendly products which has given different effects on the growth of Trigonella foenum-graecum L cultivation indeed improves the yield and quality of the plant while physical growth is also enhanced. The lower concentration of aquaponic water was acceptable to the plants Trigonella foenum- graecum $L$ because continuous supply of aquaponic water. Hence, this simple practice of application is an eco-friendly and sustainable food production system.This soil-less culture system is modern farming practices in agriculture for food security.

\section{ACKNOWLEDGMENT}

We thankful to the Research Department of Zoology, Kongunadu Arts and Science College, Coimbatore for providing the necessary lab facilities and support for this paperwork.

\section{REFERENCES}

[1] E. Altuntas, O.F. Ozgoz, and Taser," Some physical properties of fenugreek (Trigonella foenum-graceum L.) seeds", J. Food Eng., Vol.71, pp. 37-43, 2005.

[2] R.Asir Selin Kumar, and S. Saravana Babu, "Studies on the effect of seaweed extract on Oryza sativa Var. Ambai- 16 during senescence", Seaweed Research and Utilisation, Vol.26, Issue.,(1-2), pp. 171-175, 2004.

[3] S. Bernstein, "Aquaponic Gardening: A Step-by-Step Guide to Raising Vegetables and FishTogether", New Society Publishers: Gabriola Island, BC, Canada, pp. 256, 2011.

[4] S. Bernstein, Amazon, "Aquaponic Gardening: A Step-By-Step Guide to Raising Vegetable and Fish Together," [Online]. [Accessed 125 2014].

[5] K.K. Bokil, V.C. Mehta, and D.S. Datar, "Seaweeds as manure: II pot culture manorial experiments on wheat". Phykos Vol.13, issue.,1, pp. 1-5, 1974.

[6] J.S. Craigie, "Seaweed extracts stimuli in plant science and agriculture", J. Appl. Phycol. Vol. 23, pp. 371 - 393, 2011.

[7] J.Dalsgaard, I. Lund, R.Thorarinsdottir, A.Drengstig, K. Arvonen, and P.B. Pedersen, "Farming different species in RAS in Nordic countries: Current status and future perspectives", Eng., Vol, 53, pp. 2-13, 2013.

[8] S. DattaKalam, and R.Chatterjee, "Effect of different levels of nitrogen and leaf cutting on growth and seed yield of fenugreek", The Ind. J. Of Agril. SCI. Vol.75, Issue., 9, pp. 580- 581, 2005.

[9] D. De Vleesschauwer, M. Djavaheri, , P.A.H.M. Bakker, and M.Höfte, "Pseudomonas fluorescens WCS374r-induced systemic resistance in rice against Magnaporthe oryzae is based on pseudobact in-mediated priming for a salicylic acid-repressible multifaceted defense response", Plant Physiol, Vol.148, pp. 1996-2012, 2008.

[10] N. X. Durand, Briand, and C. Meyer, "The effect of marine bioactive substances (NPRS) and exogenous cytokines on nitrate reductase activity in Arabidospsis thaliana”. Physiol.Plant, Vol.119, pp. 489-493, 2003. 
[11] A.Endut, A. Jusoh, and N.Ali, "Nitrogen budget and effluent nitrogen components in aquaponics recirculation system", Water Treat, Vol.52, pp.744- 752, 2014.

[12] A.Endut, A.Jusoh, N. Ali, and W.B. Wan Nik, "Nutrient removal from aquaculture wastewater by vegetable production in aquaponics recirculation system",Desalination and Water Treatment, Vol.32, Issue., 1-3 pp. 422-430, 2011.

[13] K.Eswaran, P.K.Ghosh, A.K.Siddhanta, J.S. Patolia, C. Periyasamy, A.S. Mehta, K. H.Mody, B. K. Ramavat, K. Prasad, M. R.Rajyatguru, B.Redd, and P.A.Tewari, "Integrated method for production of carrageenan and liquid fertilizer from fresh Seaweeds", US Patent \# 6,893, pp. 479, 2005.

[14] C.Francis, G.Lieblein, S.Gliessman, T.A. Breland, N.Creamer, R. Harwood, L. Salomonsson, J.Helenius, D. Rickerl, and R.Salvador, "Agroecology: The Ecology of Food Systems", Sustain. Agric, Vol. 22, pp.99-118, 2003.

[15] A.Graber, and R. Junge, ”Aquaponic systems: nutrient recycling from fish wastewater by vegetable production" Desalination. Vol. 246, pp.147$156,2009$.

[16] T.Gurel, and G.Yusuf, "Aquaponic (Integrating Fish and Plant Culture) Systems", $2^{\text {nd }}$ International Symposium on Sustainable Development(ISSD), Sarajevo, Bosnia and Herzegovina, pp. 657-666, 2010

[17] D.D. Hong, H.M. Hien, and P.N. Son, "Seaweeds from Vietnam used for functional food medicine and biofertilizer", J. Appl. Phycol. Vol.19, pp. 817-826, 2007.

[18] H. Inden, and A. Torres, "Comparison of four substrates on the growth and quality of Tomatoes", Acta Hortic. (ISHS), Vol.644, pp.205-210, 2004.

[19] C. Kalaivanan, M.Chandrasekaran, and V.Venkatesalu, "Effect of seaweed liquid extract of Caulerpa scalpelliformis on growth and biochemical constituents of black gram (Vigna mungo (L.) Hepper)", Phykos, Vol.42, Issue., 2, pp. 46-53, 2012.

[20] W.Khan, U.P. Rayirath, S.Subramanian, M.N. Jithesh, P.Rayorath, D.M.Hodges, A.T.Critchley, J.S. Craigie, J.Norrie, and B.Prithiviraj, "Seaweed extracts as biostimulants of plant growth and development", Plant Growth Regul, Vol.28, pp.386$399,2009$.

[21] R.I. Kumari, Kaur, and A.K. Bhatnagar, "Effect of aqueous extract of Sargass johnstonii on growth, yield and quality of Lycopersicum esculentum Mill”, J. Appl. Phycol. Vol.23, pp. 623-633, 2011

[22] H. Lehman, E.A.Clark, and S.F.Weise, "Clarifying the definition of Sustainable agriculture”,.Agric. Environ. Ethics, Vol. 6, pp.127-143, 1993.

[23] J.D. Licamele, "Biomass production and nutrient dynamics in an aquaponics system", Dissertation thesis. Arizona: The University of Arizona, 2009.

[24] S. K. Malhotra, B. [24] B.Vashishtha, and V.V. Apparao," Influence of nitrogen, Azospirillum sp. and farmyard manure on growth, yield and incidence of stem gall disease in coriander (Coriandrum sativum L.)", J. of Spices and Aromatic Crops, Vol.15, Issue., 2, pp.115- 117, 2006.

[25] C.I.M. Martins, E.H. Eding, and M.C.J. Verdegem, L.T.N. Heinsbroek, O.Schneider,J.P. Blancheton, E.R.D'Orbcastel, and J.A.J.Verreth, "New developments in recirculating aquaculture systems in Europe: A perspective on environmental sustainability", Eng., Vol.43, pp. 83-93, 2010.

[26] R. S.Mehta, M. M. Anwer, O. P. Aishwath, and R. S. Meena, "Growth, yield and quality of fenugreek (Trigonella foenum-graecum L.) as influenced by nitrogen, phosphorus and bio-fertilizers", Ind. J. of Horti, Vol. 69 Issue.,1, pp. 94-97, 2012.

[27] K.Muralidhara, S.Narasimha murthy, B.S.Viswanatha, and Ramesh, "Acute and subchronicToxicity assessment of debitterized fenugreek powder in the mouse and rat Food Chem", Toxicol, Vol.37, pp. 831-838, 1999.

[28] T. Nedumaran, "Mineral composition and plant growth regulators in brown sea weed", Int. J. Cur.Tr. Res, Vol.1, Issue.,3, Pp.137-139, 2012.

[29] K. C. Nehra, H. S. Sharma, and H. R. Agarwal, "Response of fenugreek (Trigonella foenum-graecum L.) to phosphorus and potassium", Ann. Of Bio.,Vol. 18, Issue.,1, pp. 43-45, 2002.

[30] R. Nelson, and J. S. Pade, “Aquaponic food production”, Nelson and Pade, Inc., Montello,WI. Pp. 218, 2008.

[31] T. Popma, and M.P. Masser, "Tilapia: life history and biology", Southern Regional Aquaculture Center Publication, pp. $283,1999$.

[32] O.O. Otusanya, O.J. Ilori, and A.A. Adelusi, "Allelopathic effect of Tithonia diversifolia on germination and growth of Amaranthus cruentus Linn. Res”, J. Environ. Sci., Vol.1, pp. 285-293, 2007.

[33] B. Pramanick, K. Brahmachari, A.Ghosh, and S. Zodape, "Effect of seaweed saps on growth and yield improvement of transplanted rice in old alluvial soil of west Bengal", Bangladesh J. Bot, Vol. 43, Issue.,1, pp. 53-58, 2014.

[34] J.E. Rakocy, "Aquaponics—Integrating Fish and Plant Culture”, Wiley-Blackwell, Hoboken, NJ, USA, pp. 344-386, 2012.

[35] J.E. Rakocy, M.P. Masser, and T.M.Losordo, "Recirculating Aquaculture Tank Production Systems:Aquaponics-Integrating Fish and Plant Culture", Southern Regional Aquaculture Center: Stoneville, MS, USA, pp. 1-16, 2006.

[36] J. Rakocy, R.C. Shultz, D.S. Bailey, and E.S. Thoman, "Aquaponic production of tilapia and basil: Comparing a batch and staggered cropping system", Acta Hortic. Vol. 648, pp.63-69, 2004.

[37] LH.Ramarajan, AS.Joseph, and Ganthi, "Effect of Seaweed Liquid Fertilizer on the Germination and Pigment Concentration of Soybean", Journal of Crop Science and Technology, Vol.1, pp.1-5. 2012.

[38] H.R. Roosta, and M.Hamidpour, "Effects of foliar application of some macro- and micro nutrients on tomato plants in aquaponic and hydroponic systems”, Sci. Hortic. Vol.129, pp.396-402, 2011.

[39] KJ.Sanderson, PE. Jameson, "The cytokinins in a liquid seaweed extract: could they be the active ingredients?", Acta Hort (ISHS), Vol.179, pp. 113-116, 1986.

[40] IJ. Schalk, M. Hannauer, A. Braud, "New roles for bacterial siderophores in metal transport and tolerance", Environ Microbiol, Vol. 2011, Issue.,13, pp.2844-2854, 2011.

[41] R. Sekar, N.Thangaraju, and R.Rengasamy, "Effect of seaweed liquid fertilizer from Ulva lactuca on Vigna unguiculata L. (Walp)", Phykos Vol.34, pp.49-53, 1995.

[42] D. K. Sharma, L. K. Dashora, and N. L.Sen, "Influence of phosphorus rich organic manure (PROM),PSB and Rhizobium inoculation on growth and yield of fenugreek (Trigonella foenum- graecum L.) cv. Rmt-Orissa", J. of Horti. Vol. 34 Issue., 1, pp. 52-58, 2006.

[43] C.Sonneveld, and W.Voogt, "Plant Nutrition in Future Greenhouse Production. In Plant Nutrition of Greenhouse Crops", Springer: Heidelberg, The Netherlands,; pp. 393-403, 2009.

[44] K.Srinivasan, "Fenugreek (Trigonella foenum-graecum): a review of health beneficial physiological effects Food", Rev. Int., Vol.2, pp. 203224, 2006 
[45] S.Subramanian, M.Vijayakumar,"Effect of various levels of nitrogen and Azospirillum on growth and yield of CO 3 coriander (Coriandrum sativum L.)", South Indian Horticulture. Vol. 49, pp.191-194, 2001.

[46] L. Taiz and E. Zeiger, Plant Physiology. 5th Edition, Sinauer Associates Inc., Sunderland, Americal journal of plant sciences. pp.782, 2010

[47] N.Tomasi, C.Rizzardo, R. Monte, S. Gottardi, N.Jelali, R.Terzano, B.Vekemans, M.deNobili, Z.Varanini, R.Pinton, and S.Cesco, "Microanalytical, physiological and molecular aspects of $\mathrm{Fe}$ acquisition in leaves of Fe-deficient tomato plants re-supplied with natural Fe-complexes in nutrient solution", Plant Soil, Vol.325, pp. 25-38, 2009.

[48] J.E. Thomas, M. Bandara, E.L Lee, D. Driedger, and S.Acharya, "Biochemical monitoring in fenugreek to develop functional food and medicinal plant variants New Biotechnol", Vol. 2, pp. 110-117, 2011.

[49] A.E.Turcios, J.Papenbrock, "Sustainable Treatment of Aquaculture Effluents-What Can We Learn from the Past for the Future? Sustainability", Vol. 6, pp.836-856, 2014

[50] R.V.Tyson, E.H. Simonne, D.D. Treadwell, J.M. White, and A.Simonne, "Reconciling pH for ammonia biofiltration and cucumber yield in a recirculating aquaponic system with perlite biofilters", HortScience, Vol. 43, pp. 719-724, 2008.

[51] M.Villarroel, J.M.R. Alvarino, and J.M. Duran, "Aquaponics: integrating fish feeding rates and ion waste production for strawberry hydroponics”, Span. J. Agric. Res. Vol. 9, Issue., 2, pp. 537-545, 2011.

[52] X .Zhang, and E.H. Ervin, "Cytokinin-containing seaweed and humic acid extracts associated with creeping bentgrass leaf cytokinins and drought resistance", Crop. Sci. Vol. 44, pp. 1737-1745. 2004.

[53] X.Zhang, and E.H. Ervin,. Impact of seaweed extract-based cytokinins and zeatin riboside on creeping bentgrass heat tolerance. Crop. Sci. Vol.48, pp. 364-370, 2008.

[54] S.T. Zodape, A. Gupta, and S.C. Bhandari, "Foliar application of seaweed sap as biostimulant for enhancement of yield and quality of tomato (Lycopersicon esculentum Mill.)“, J. Sci. Ind. Res.Vol.70, pp.215-219, 2011.

[55] S. T. Zodape, V. J.Kawarhe, J. S. Patolia, and A. D. Warade, "Effect of liquid seaweed fertilizer on yield and quality of okra Abelmoschus esculentus L.”, Seaweed Res. Utiln. Vol. 67, pp.1115-1117, 2008. 